\title{
PENGARUH SKEMA PEMBIAYAAN BAGI HASIL, CADANGAN KERUGIAN PEMBIAYAAN DAN BIAYA DANA TERHADAP LABA/RUGI
}

\author{
Eko Bagus Cahyo Purnomo \\ Program Studi Magister Sains Ekonomi Islam, Fakultas Ekonomi dan Bisnis \\ Universitas Airlangga \\ Email : eko.bagus.cahyo-2018@pasca.unair.ac.id
}

\begin{abstract}
ABSTRAK
Penelitian ini bertujuan untuk menguji dan menganalisis pengaruh skema pembiayaan bagi hasil, cadangan kerugian pembiayaan atau cadangan kerugian penurunan nilai yang disingkat CKPN dan biaya dana terhadap kasus studi laba/rugi di salah satu bank syariah di Jawa Timur pada 2016-2018 menggunakan data rahasia. Pengumpulan data diambil secara rahasia yang mudah diperoleh karena merupakan bagian dari pekerjaan penulis. Analisis data dalam penelitian ini menggunakan E-Views versi 10. Teknik yang digunakan dalam penelitian ini termasuk kumpulan kuadrat terkecil, statistik deskriptif, tes normalitas dan tes heteroskedastisitas. Analisis menunjukkan bahwa cadangan kerugian penurunan nilai memiliki pengaruh signifikan terhadap kinerja laba/rugi sementara skema pembiayaan bagi hasil tidak cukup berpengaruh.
\end{abstract}

Kata kunci : Pembiayaan Bagi Hasil, Cadangan Kerugian, Biaya Dana, Laba Rugi .

\begin{abstract}
This study aimed to examine and analyze the influence of a scheme of profit-sharing financing, impairment losses or allowance for impairment losses abbreviated as CKPN and cost of funds against a case study of profit \& loss in one of Sharia banks in East Java within 2016-2018 by using confidential data. Data were collected confidentially and easy to be collected since it was a part of the author's job. Data analysis in this study was done using E-Views version 10. The technique used in this study included Ordinary Least Squares (OLS), descriptive statistics, normality test, and heteroscedasticity test. The analysis showed that the allowance for impairment losses influenced the performance of profit/loss significantly, while the scheme of profit-sharing financing did not give enough influence.
\end{abstract}

Keywords : Profit-sharing Financing, Allowance for Impairment Losses, Cost of Funds, Profit \& Loss. 


\section{PENDAHULUAN}

Bank merupakan salah satu lembaga keuangan yang disebut sebagai lembaga intermediasi sehingga memungkinkan adanya pengalihan asset (asset transmutations), relokasi pendapatan (income realocation), transaksi (transaction), likuiditas (liquidity) dan efisiensi (efficiency). Keberadaan lembaga keuangan juga memiliki manfaat untuk menyelesaikan persoalan-persoalan yang muncul saat terjadi transaksi keuangan secara langsung yaitu persoalan likuiditas, keamanan, kenyamanan, aksesbilitas, dan tingkat bunga. (Manurung dan Rahardja, 2004)

Pada masa sekarang Perbankan Syariah benar-benar sedang dihadapkan pada masalah fluktuasi ekonomi yang tidak menentu. Kenapa hanya perbankan syariah yang paling berimbas terhadap hal tersebut. Karena bank syariah mayoritas bisnisnya mendukung sektor riil untuk memperoleh laba, berbeda dengan bank konvensional yang masih diperbolehkan untuk memperoleh laba melalui intrumen pasar uang bahkan ada bank konvensional yang pendapatannya hampir $50 \%$ dari aktifitas transaksi di pasar uang melalui divisi treasuri di bank konvensional tersebut. Belum lagi beban pembentukan cadangan kerugian penurunan nilai/CKPN yang beban terbesarnya disebabkan oleh pembiayaan macet. Apalagi sektor riil di Indonesia seperti pertambangan, hasil perkebunan komoditi ekspor harganya sempat anjlok dan sangat mempengaruhi kinerja perbankan syariah.

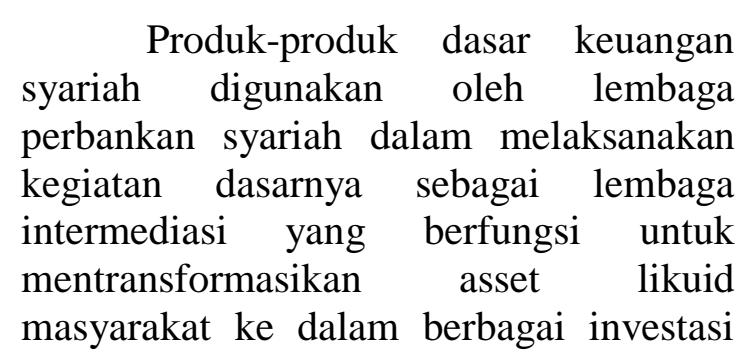

jangka panjang. (Darsono dan Enny, 2017)

Sistem perbankan Islam yang berkembang saat ini memiliki pengaruh yang cukup signifikan dalam upaya meningkatkan perekonomian masyarakat dan kesadaran baru untuk mengadopsi dan memperluas lembaga keuangan Islam Krisis perbankan yang telah terjadi sejak 1997 telah mengindikasikan bahwa bank yang beroperasi berdasarkan prinsip syariah dapat bertahan karena naik turun atau fluktuasi nilai tukar mata uang dan suku bunga yang tinggi. Pada saat yang sama, bank konvensional tidak memiliki dana cash yang cukup untuk kegiatan operasional mereka. Para debitur dari customer memiliki ketidakmampuan untuk membayar kembali dana kredit karena tingkat bunga yang cukup tinggi. Hancurnya bank konvensional telah menjadi pelajaran bagi para pembuat kebijakan moneter untuk mencoba menerapkan alternatif di dalam sistem moneter. Dan telah diyakini bahwa sistem manajemen dalam ekonomi Islam adalah solusi untuk membangun kembali sistem ekonomi Indonesia. Ulama' ahli fiqih dan bankir Islam di dunia Islam menegaskan bahwa bunga yang diterapkan di perbankan konvensional adalah riba dan riba dilarang atau haram (Zaenudin dan Erlina, 2013).

Berdasarkan latar belakang di atas dapat di ambil rumusan masalah bagaimana pengaruhnya skema pembiayaan bagi hasil dan cadangan kerugian penurunan nilai/CKPN terhadap laba/rugi studi kasus pada salah satu bank syariah di Jawa Timur tahun 2016-2018.

Berdasarkan tujuan pada penelitian ini adalah untuk mengetahui bagaimana pengaruh skema pembiayaan bagi hasil dan cadangan kerugian penurunan nilai/CKPN terhadap laba/rugi studi kasus pada salah satu bank syariah di Jawa Timur tahun 2016-2018. 


\section{TINJAUAN PUSTAKA}

Menurut peneliti akad bagi hasil adalah skema yang paling tepat dalam skema sebuah pembiayaan syariah, terutama pembiayaan untuk usaha produktif. Bagi hasil dalam skema akad mudharabah dan musyarakah ini sampai dengan saat ini bukan portofolio favorit dalam laporan keuangan perbankan syariah pada umumnya. Akad jual beli atau murabahah masih menjadi primadona atau portofolio terbesar dalam laporan keuangan perbankan syariah. Mungkin akad mudharabah dan musyarakah dipandang tidak terlalu menguntungkan di pasar perbankan syariah, padahal menurut (Abbas dan Arizah, 2019) perbankan syariah kurang optimal memasarkan produk pembiayaan mudharabah dan musyarakah kepada masyarakat umum. Padahal pembiayaan mudharabah dan musyarakah cukup signifikan mempengaruhi profitabilitas perbankan syariah.

Menurut penelitian dari (Riyadi dan Yulianto, 2014) pembiayaan dengan skema bagi hasil merupakan salah satu produk perbankan syariah yang disalurkan kepada nasabah, pembiayaan skema bagi hasil cukup berpengaruh terhadap profitabilitas. Besar kecilnya nilai pembiayaan dengan skema bagi hasil akan berpengaruh terhadap pendapatan yang dihasilkan dan akan mempengaruhi profitabilitas (laba) yang akan didapat. Sebab dengan adanya pembiayaan dengan skema bagi hasil yang disalurkan kepada nasabah, perbankan syariah mengharapkan akan mendapatkan pendapatan dan nisbah bagi hasil atas pembiayaan yang diberikan kepada nasabah yang kemudian bagi hasil tersebut menjadi laba bank syariah.

Profitabilitas merupakan hal yang sangat penting untuk menunjukkan kemampuan manajemen dalam mengelola asetnya, karena regulator dan pemegang kontrol moneter yakni Bank Indonesia sebagai pengawas perbankan lebih memprioritaskan nilai profitabilitas suatu bank, dengan diukur aset yang dananya sebagian besar dari dana pihak ketiga atau dana simpanan masyarakat. Semakin besar ROA suatu bank, semakin besar pula tingkat laba yang dicapai bank, dan semakin baik pula posisi bank dari segi penggunaan dan pengelolaan aset (Dendawijaya, 2009).

Besar dan kecilnya perusahaan juga menjadi salah satu pertimbangan bagi stakeholder dalam melakukan investasi. Secara teoritis, perusahaan yang lebih besar biasanya memiliki kepastian dan tingkat pengembalian investasi yang lebih besar daripada perusahaan yang lebih kecil sehingga mengurangi resiko mengenai prospek perusahaan ke depan. Hal tersebut dapat membantu para investor dalam memprediksi resiko yang mungkin terjadi jika investor berinvestasi di perusahaan tersebut.

Perbankan Syariah didirikan berdasarkan alasan filosofis maupun praktik. Secara filosofis perbankan syariah didirikan berdasarkan dilarangnya pengambilan riba dalam transaksi keuangan maupun non keuangan. Secara praktis perbankan syariah tidak mengenal konsep bunga dan tidak mengenal peminjaman uang tetapi yang ada adalah kemitraan/kerjasama (mudharabah dan musyarakah) dengan prinsip bagi hasil, sementara peminjaman uang hanya dimungkinkan untuk tujuan sosial tanpa adanya imbalan apapun. (Mokoagow dan Fuady, 2015)

Peranan perbankan syariah dalam aktifitas ekonomi di Indonesia tidak jauh berbeda dengan perbankan konvensional (Banoon, 2007). Peran dan fungsi perbankan syariah sangat penting dalam perkembangan lembaga keuangan syariah di Indonesia khususnya bank syariah, maka kinerja bank syariah perlu 
ditingkatkan agar tercipta perbankan dengan prinsip syariah yang sehat. Kinerja merupakan hal yang penting bagi perusahaan, karena bisnis perbankan adalah bisnis kepercayaan, maka bank harus mampu menunjukkan kredibilitasnya sehingga akan semakin banyak masyarakat yang menggunakan jasa perbankan dalam bertransaksi, salah satunya melalui peningkatan profitabilitas (Kasmir, 2010). Profitabilitas merupakan salah satu indikator yang tepat untuk mengukur kinerja perusahaan (Suryani, 2011), karena kemampuan perusahaan menghasilkan laba dapat menjadi tolak ukur kinerja perusahaan.

Profitabilitas bank syariah dalam kegiatan bisnisnya dapat dipengaruhi oleh beberapa faktor. Faktor eksternal yang terkait dengan kondisi makroekonomi dalam kegiatan bisnis syariah diantaranya meliputi tingkat inflasi, tingkat suku bunga (BI rate) dan kurs. Inflasi mencerminkan kenaikan harga barang dan jasa dalam perekonomian pada periode waktu tertentu. Semakin tinggi inflasi semakin tinggi pula harga-harga barang dan jasa dalam perekonomian. Penelitian mengenai pengaruh inflasi terhadap profitabilitas bank pernah dilakukan oleh (Molyneux dan Thornton, 1992) dengan menggunakan indikator consumer price index (CPI) sebagai proksi dari inflasi. Hasilnya menunjukkan bahwa inflasi memiliki hubungan yang signifikan terhadap tingkat keuntungan bank dalam kegiatannya.

\section{Skema Pembiayaan Bagi Hasil}

Dalam konteks perbankan dan keuangan Islam pembiayaan skema bagi hasil bisa menggunakan dua akad yaitu mudharabah dan musyarakah, secara teknis mudharabah adalah kemitraan laba dimana satu pihak (rabbul mal) menyediakan modal dan pihak lain (mudharib) menyediakan tenaga kerja. Sementara itu definisi musyarakah menurut AAOIFI di dalam standar Syariah No. 12, Klausul 2/1 yang diterbitkannya, mendefinisikan sebagai "perjanjian di antara dua pihak atau lebih untuk mengkombinasikan asset, tenaga kerja, atau liabilitas mereka, demi alasan menghasilkan laba.

Pada dasar konsepnya pembiayaan dengan skema bagi hasil merupakan konsep pembiayaan yang bisa dilakukan dua pola jenis penggunaan, untuk investasi atau untuk modal kerja. Dalam hal investasi pola pembiayaan skema bagi hasil dengan akad mudharabah, pembiayaan investasi tersebut dapat sepenuhnya dicover $100 \%$ oleh sohibul mal kepada mudharib, pembiayaan akad mudharabah merupakan akad amanah, posisi mudharib sebagai pemegang amanah terhadap modal, mudharib tidak bertanggung jawab atas kegagalan proyek dan tidak wajib menyerahkan ganti rugi.

Sohibul mal menanggung resiko kerugian dengan prinsip keseimbangan yaitu hak keuntungan sama dengan tanggung jawab resiko apabila nanti ada kerugian. Jika modal yang diamanahkan kepada mudharib sukses mendapatkan keuntungan maka keuntungan akan dibagi sesuai dengan kesepakatan diawal antara mudharib dan sohibul mal. Pembagian keuntungan yang disepakati bisa disebut nisbah. Nisbah adalah porsi bagi hasil antara mudharib dan sohibul mal atas transaksi akad mudharabah.

Pada prinsipnya dalam penyaluran mudharabah tidak ada jaminan, namun agar pengelola dana tidak melakukan penyimpangan maka pemilik dana dapat meminta jaminan dari pengelola dana atau pihak ketiga. Jaminan ini hanya dapat dicairkan apabila pengelola dana terbukti melakukan pelanggaran terhadap hal-hal yang telah disepakati bersama dalam akad.

$$
\text { Pengembalian dana syirkah }
$$
temporer dapat dilakukan secara parsial bersamaan dengan distribusi bagi hasil 
atau secara total pada saat akad mudharabah diakhiri. Jika dari pengelolaan dana syirkah temporer menghasilkan keuntungan maka porsi jumlah bagi hasil untuk pemilik dana dan pengelola dana ditentukan berdasarkan nisbah yang disepakati dari hasil usaha yang diperoleh selama periode akad. Jika dari pengelolaan dana syirkah temporer menimbulkan kerugian maka kerugian finansial menjadi tanggungan pemilik dana.

Pembagian hasil usaha mudharabah dapat dilakukan berdasarkan prinsip bagi hasil atau bagi laba. Dalam prinsip bagi hasil usaha berdasarkan bagi hasil, dasar pembagian hasil usaha adalah laba bruto (grossprofit) bukan total pendapatan usaha (omset). Sedangkan dalam prinsip bagi laba, dasar pembagian adalah laba bersih yaitu laba bruto dikurangi beban yang berkaitan dengan pengelolaan modal mudharabah.

Jika nilai investasi mudharabah turun sebelum usaha dimulai disebabkan rusak, hilang atau faktor lain yang bukan kelalaian atau kesalahan pihak pengelola dana, maka penurunan nilai tersebut diakui sebagai kerugian dan mengurangi saldo investasi mudharabah. Jika sebagian investasi mudharabah hilang setelah dimulainya usaha tanpa adanya kelalaian atau kesalahan pengelola dana, maka kerugian tersebut diperhitungkan pada saat bagi hasil. Usaha mudharabah dianggap mulai berjalan sejak dana atau modal usaha mudharabah diterima oleh pengelola dana. Dalam investasi mudharabah yang diberikan dalam bentuk barang (nonkas) dan barang tersebut mengalami penurunan nilai pada saat atau setelah barang dipergunakan secara efektif dalam kegiatan usaha mudharabah, maka kerugian tersebut tidak langsung mengurangi jumlah investasi namun diperhitungan pada saat pembagian bagi hasil.

Jika investasi mudharabah melebihi satu periode pelaporan, penghasilan usaha diakui dalam periode terjadinya hak bagi hasil sesuai nisbah yang disepakati. Kerugian yang terjadi dalam suatu periode sebelum akad mudharabah berakhir diakui sebagai kerugian dan dibentuk penyisihan kerugian investasi. Pada saat akad mudharabah berakhir, selisih antara:

a) Investasi mudharabah setelah dikurangi penyisihan kerugian investasi; dan

b) Pengembalian investasi mudharabah; diakui sebagai keuntungan atau kerugian.

Pengakuan penghasilan usaha mudharabah dalam praktik dapat diketahui berdasarkan laporan bagi hasil atas realisasi penghasilan usaha dari pengelola dana. Tidak diperkenankan mengakui pendapatan dari proyeksi hasil usaha. Kerugian akibat kelalaian atau kesalahan pengelola dana dibebankan pada pengelola dana dan tidak mengurangi investasi mudharabah. Bagian hasil usaha yang belum dibayar oleh pengelola dana diakui sebagai piutang jatuh tempo dari pengelola dana.

Berikut ini adalah gambaran skema pembiayaan dengan akad mudharabah: 


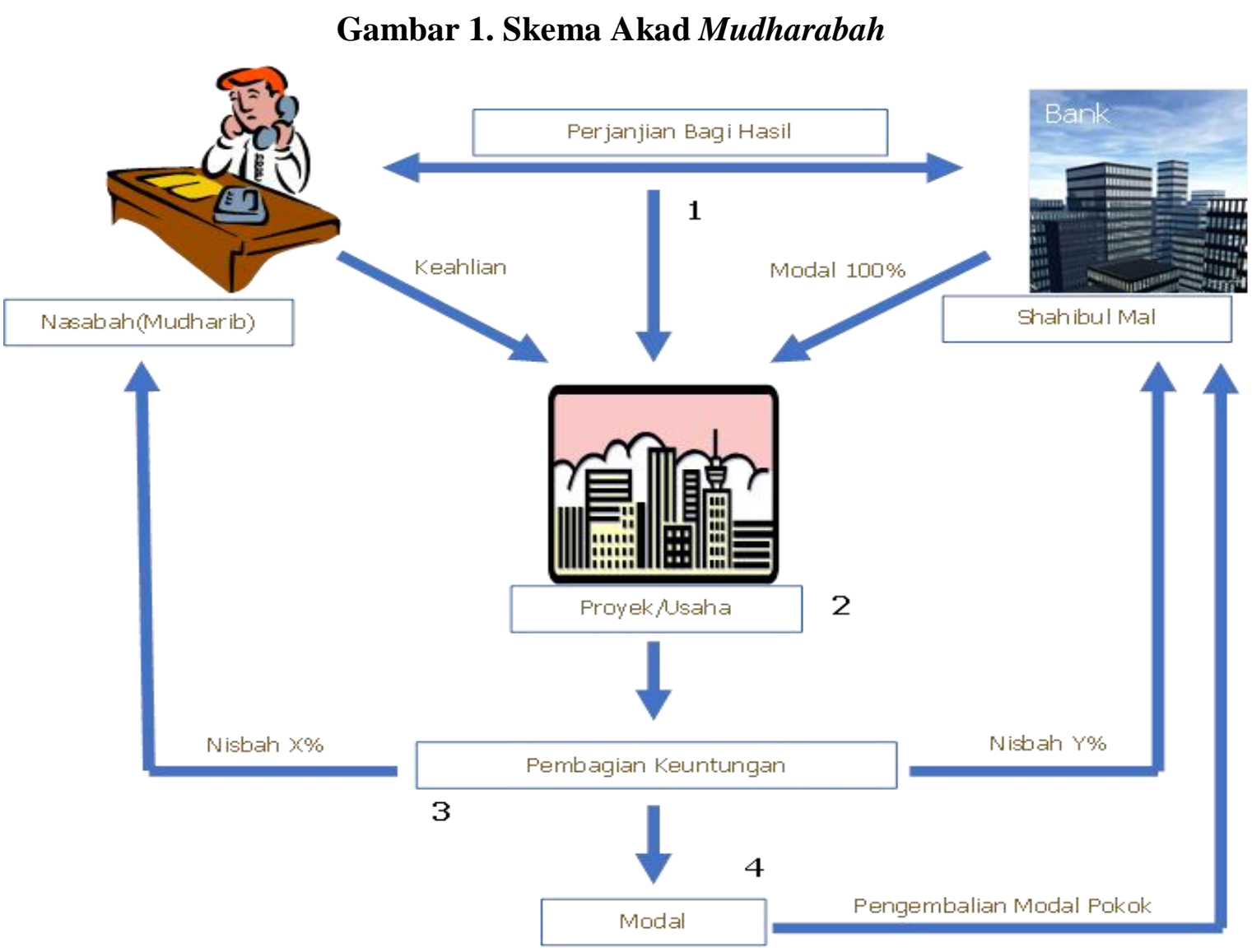

\section{Keterangan:}

(1) Adanya perjanjian akad bagi hasil antara shahibul mal dan mudharib.

(2) Shahibul mal menyerahkan modal $100 \%$ sementara mudharib memberikan sepenuhnya keahliannya dalam usaha yang dijadikan objek akad.

(3) Jika proyek atau usaha yang dijadikan objek akad itu menghasilkan keuntungan akan dibagikan sesuai porsi nisbah yang disepakati.

(4) Pengembalian modal kepada shahibul mal dapat dilakukan secara bertahap maupun langsung sesuai dengan kesepakatan yang telah dibuat.

Akad skema pembiayaan bagi hasil selanjutnya adalah musyarakah. Musyarakah adalah akad kerjasama antara dua pihak atau lebih untuk suatu usaha tertentu dimana masing-masing pihak memberikan kontribusi dana dengan kesepakatan bahwa keuntungan dan resiko akan ditanggung bersama sesuai dengan porsi kontribusi dana atau kesepakatan bersama.

Karakteristik akad musyarakah adalah kerjasama antara pemilik dana yang menggabungkan dana mereka untuk tujuan mencari keuntungan, membiayai suatu proyek tertentu dimana mitra dapat mengembalikan dana tersebut berikut bagi hasil yang disepakati baik secara bertahap maupun sekaligus, dapat diberikan alam bentuk kas setara kas dan aktiva non kas atau aktiva tidak berwujud, seperti lisensi hak paten dan sebagainya.

Berikut ini adalah gambaran skema pembiayaan dengan akad musyarakah: 


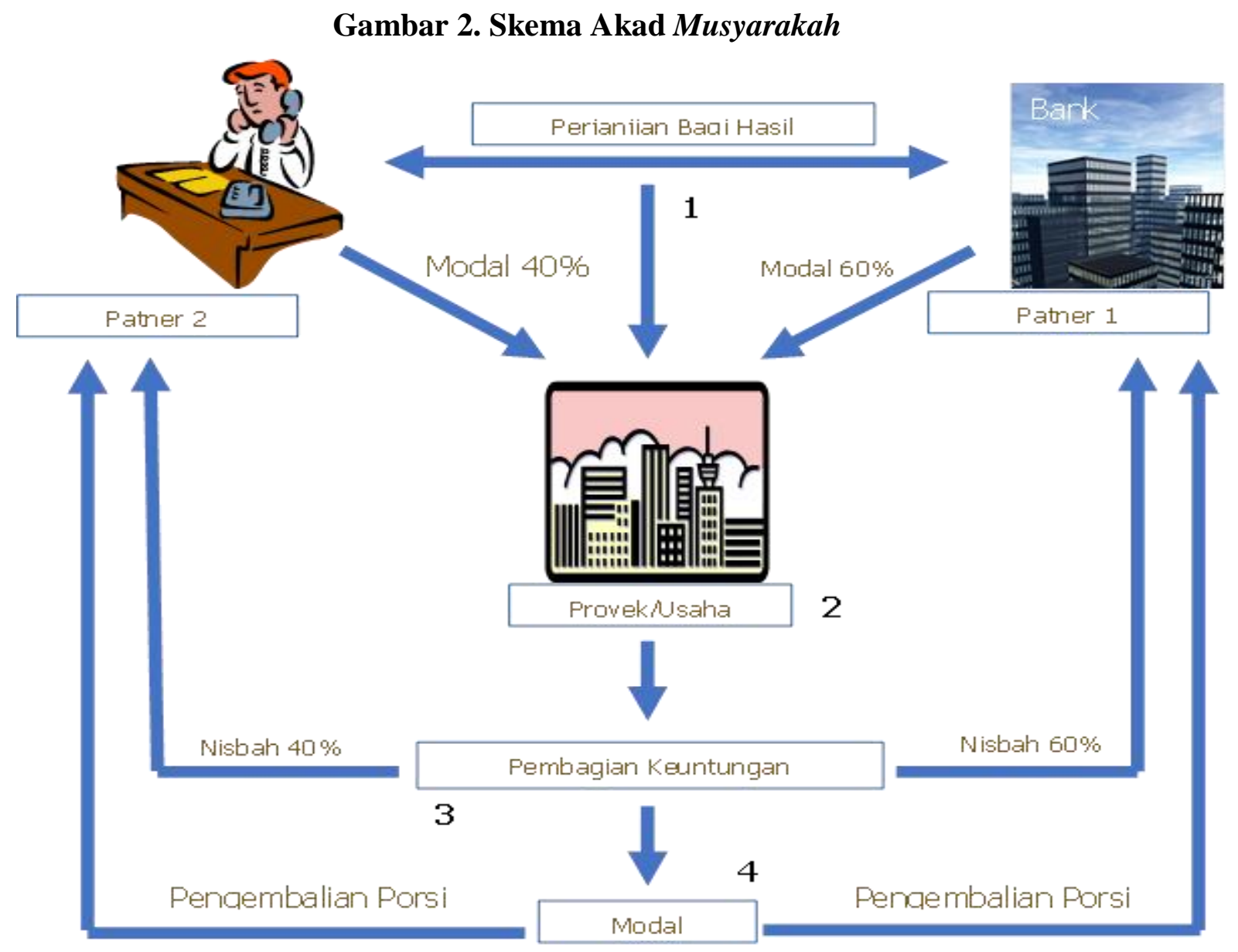

Keterangan: (1) Adanya perjanjian akad bagi hasil antara patner 1 dan patner 2. (2) Masing-masing patner menyerahkan modal sesuai porsi persentase yang disepakati dalam usaha yang dijadikan objek akad. (3) Jika proyek atau usaha yang dijadikan objek akad itu menghasilkan keuntungan akan dibagikan sesuai porsi modal yang disepakati. (4) Pengembalian modal dapat dilakukan secara bertahap maupun langsung sesuai dengan kesepakatan yang telah dibuat.

\section{Cadangan Kerugian Penurunan Nilai/CKPN}

Menurut Peraturan Otoritas Jasa Keuangan nomor 16/POJK.03/2014 tentang Penilaian Kualitas Aset Bank Umum Syariah dan Unit Usaha Syariah, cadangan kerugian penurunan nilai yang selanjutnya disebut CKPN adalah penyisihan yang dibentuk apabila nilai tercatat aset keuangan setelah penurunan nilai kurang dari nilai tercatat awal. CKPN ini dapat dikatakan sebagai cadangan kerugian atas realisasi pembiayaan.

Dalam perhitungan CKPN untuk skema pembiayaan bagi hasil (akad mudharabah dan musyarakah) masih menggunakan konsep lama Penyisihan Penghapusan Aset Produktif yang disingkat PPAP. Menurut POJK nomor 16/POJK.03/2014 pasal 43 ayat 1 sampai 3 cara perhitungannya adalah sebagai berikut :

1. Cadangan umum PPA sebagaimana dimaksud dalam Pasal 42 ayat (2) huruf a, ditetapkan paling rendah sebesar $1 \%$ (satu perseratus) dari seluruh Aset Produktif yang digolongkan lancar. 
2. Cadangan umum PPA sebagaimana dimaksud pada ayat (1) Tidak berlaku bagi Aset Produktif dalam bentuk:

a. Fasilitas Pembiayaan yang belum ditarik yang merupakan bagian dari TRA.

b. SBIS, SBSN, dan/atau penempatan dana lain pada Bank Indonesia dan/atau Pemerintah Indonesia.

c. bagian Aset Produktif yang dijamin dengan jaminan Pemerintah Indonesia atau agunan tunai sebagaimana dimaksud dalam Pasal 29; dan/atau

\section{d. Pembiayaan Ijarah dan Pembiayaan Ijarah Muntahiya Bittamlik.}

3. Cadangan khusus PPA sebagaimana dimaksud dalam Pasal 42 ayat (2) ditetapkan paling rendah sebesar:

a. 5\% (lima perseratus) dari Aset Produktif yang digolongkan dalam perhatian khusus setelah dikurangi nilai agunan.

b. $15 \%$ (lima belas perseratus) dari Aset Produktif dan Aset Non Produktif yang digolongkan kurang lancar setelah dikurangi nilai agunan.

c. $50 \%$ (lima puluh perseratus) dari Aset Produktif dan Aset Non Produktif yang digolongkan diragukan setelah dikurangi nilai agunan; atau

d. $100 \%$ (seratus perseratus) dari Aset Produktif dan Aset Non Produktif yang digolongkan macet setelah dikurangi nilai agunan.

\section{Biaya Dana}

Biaya dana atau yang dikenal dengan Cost of Funds adalah biaya yang harus dikeluarkan bank untuk setiap rupiah dana yang dihimpunnya dari berbagai sumber sebelum dikurangi dengan likuiditas wajib minimum yang harus selalu dipelihara oleh bank. Biaya dana adalah salah satu biaya input yang paling penting untuk lembaga keuangan karena biaya yang lebih rendah akan menghasilkan pengembalian yang lebih baik ketika dana tersebut digunakan untuk pinjaman jangka pendek dan jangka panjang kepada peminjam.

\section{Unsur-unsur Biaya Dana}

(1) Sumber Dana : Jenis-jenis dana yang dapat dihimpun bank, bisa dari dana sendiri maupun dana yang berasal dari luar, yang mana dalam perhitungannya sumber dana ini dibagi dua yaitu dana berbiaya dan dana tidak berbiaya.

(2) Jumlah Dana : Jumlah semua dana yang dapat dihimpun bank, baik dana dari dalam maupun dari luar.

(3) Loanable Fund : Dana yang dapat dialokasikan untuk pemberian kredit atau untuk pembelian surat-surat berharga dengan tujuan memperoleh penghasilan.

(4) Unloanable Fund : Dana yang tidak dapat dialokasikan untuk pemberian kredit dan investasi lainnya. Dana ini diperuntukkan bagi aktiva tetap dan pengelolaan likuiditas.

(5) Reserve Requirement : Dana yang ditahan bank untuk kepentingan likuiditas, besarnya dana ini akan ditentukan oleh Bank Indonesia.

\section{Faktor-faktor yang Mempengaruhi Biaya Dana}

Biaya Dana adalah tingkat suku bunga yang dibayar; komposisi dari portofolio sumber dana; ketentuan mengenai cadangan wajib minimum (reserve requirement); biaya pelayanan untuk mendapatkan dana (service cost); pajak atas bunga tahun efisiensi. 


\section{Laba Dan Rugi.}

Laporan keuangan yang melaporkan kinerja keuangan perusahaan dalam periode waktu tertentu. Laporan laba rugi meringkas jumlah biaya-biaya yang dikeluarkan perusahaan selama beroperasi serta keuntungan yang diperoleh perusahaan selama menjalankan usaha.

\section{METODE PENELITIAN}

\section{Sumber Data}

Data ini merupakan data primer yang didapatkan secara confidential karena profesi yang penulis memiliki akses untuk mendapatkan data tersebut di salah satu bank syariah di Jawa Timur. Data yang diolah diperkecil dalam jutaan rupiah.

\section{Definisi Operasional Variabel}

\section{Laba / Rugi (Y)}

Variabel dependen yaitu laba/rugi, laba/rugi adalah laporan keuangan yang melaporkan kinerja keuangan perusahaan dalam periode waktu tertentu. Laporan laba rugi meringkas jumlah biaya-biaya yang dikeluarkan perusahaan selama beroperasi serta keuntungan yang diperoleh perusahaan selama menjalankan usaha.

Variabel Independen (X). Skema Pembiayaan Bagi Hasil (mudharabah dan musyarakah) (X1). Cadangan Kerugian Penurunan Nilai / CKPN (X2).

\section{Uji Normalitas}

Sebelum data dianalisis dengan analisis regresi linier, mereka terlebih dahulu akan diuji dengan menggunakan tes normal, untuk memeriksa apakah dalam model regresi, variabel dependen dan variabel independen keduanya memiliki atau berdistribusi normal atau tidak, regresi yang baik model harus memiliki distribusi data normal atau hampir normal. Jika hipotesis ini dilanggar, uji statistik menjadi tidak valid untuk sejumlah sampel. Tes $F$ mengasumsikan bahwa nilai residu mengikuti distribusi normal. Untuk menguji normalitas residual, uji statistik non-parametrik Kolmogorov-Smirnov (KS) digunakan. Tes K-S dilakukan dengan membuat hipotesis:

HO : Data residual terdistribusi normal

$\mathrm{Ha}$ : Data residual tidak terdistribusi normal

Distribusi data normal dilakukan dengan mengamati nilai signifikansi variabel. Proses pengambilan keputusan tentang normalitas adalah sebagai berikut:

a. Jika $p<0,05$ distribusi data tidak normal b. Jika $p>0,05$ distribusi data normal

\section{Uji Asumsi Klasik}

\section{Uji Multikolinearitas}

Menurut uji multikolinieritas, kami bermaksud memverifikasi apakah model regresi telah menemukan korelasi antara variabel independen Cara mendeteksi multikolinieritas dengan mengamati nilai Variance Inflation Factor (VIF) dan Toleransi. Batas VIF adalah 10 dan nilai Toleransi adalah 0,1 . Jika nilai VIF lebih besar dari 10 dan nilai Toleransi kurang dari 0,1 . terjadi multikolinieritas. Jika ada variabel independen yang dipengaruhi oleh multikolinearitas.

\section{Uji Heterokedasitas}

Uji heteroskedastisitas digunakan untuk mendeteksi apakah dalam varian model regresi terdapat ketidaksetaraan residual, pengamatan terhadap pengamatan lain. Jika varian dari pengamatan ke pengamatan lain tetap, maka itu disebut homoschedosity atau tidak ada heterokedastisitas. Jika varian yang berbeda disebut heterokedastisitas. Model regresi yang baik adalah bahwa homoseksualitas atau heteroskedastisitas tidak terjadi. 


\section{Uji Autokolerasi}

Autokolerasi hanya ditujukan terhadap data berdasarkan pada runtun waktu. Uji Autokolerasi merupakan adanya kolerasi diantar anggota observasi yang diurut menurut waktu (seperti deret berkala). Salah satu cara dapat digunakan untuk mendeteksi ada atau tidak autokolerasi adalah dengan Durbin Waston (d). Hasil dari perhitungan Durbin Waston (d) dibandingkan dengan nilai $\mathrm{d}$ table pada $\alpha=0,05$. Tabel $\mathrm{d}$ memiliki dua nilai, yaitu nilai batas (du) dan nilai batas bawah (d1) untuk berbagai nilai $\mathrm{n}$ dan $\mathrm{k}$ (Sanusi, 2011).

\section{Analisis Regresi Linier Berganda}

Persamaan model regresi linier
berganda yang digunakan dalam
penelitian ini yaitu:

$\mathrm{Y}=\alpha+\beta 1 \mathrm{X} 1+\beta 2 \mathrm{X} 2+\beta 3 \mathrm{X3}+\mathrm{e}$ (1)

Dimana :

$\mathrm{Y}=$ Laba/Rugi, nominal yang terbentuk pada laba/rugi bersih dalam laporan laba rugi.

$\alpha=$ Konstanta.

$\beta=$ Koefisien Regresi (nilai peningkatan atau penurunan).

$\mathrm{X} 1=$ Variabel Independen Skema Pembiayaan Bagi Hasil, yaitu nominal yang terbentuk dalam neraca aktiva posisi pembiayaan mudharabah.

$\mathrm{X} 2=$ Variabel Independen $\mathrm{CKPN}$, yaitu nominal yang terbentuk dalam laporan laba rugi posisi CKPN.

$\mathrm{X} 3=$ Variabel Independen Biaya Dana, yaitu nominal yang terbentuk dalam laporan laba rugi posisi biaya dana

e $\quad=$ Standard Erorr

\section{Pengujian Hipotesis}

\section{Uji t}

Dalam uji $\mathrm{T}$ ini bertujuan untuk menilai pengaruh variabel independen terhadap variabel dependen secara parsial. Uji secara parsial diperlukan agar mengetahui signifikan tidaknya pengaruh masig-masing variabel (X) terhadap variabel $(\mathrm{Y})$. Data penelitian ini diolah menggunakan program E-Views, pengaruh secara individual ditunjukan dari nilai signifikan uji t. Hasil uji t dapat dilihat pada tabel coefficient pada kolom prob (significance) jika hasil nilai signifikan uji $\mathrm{t}<0,05$ maka dapat disimpulkan terdapat pengaruh yang sigifikan secara individual masing-masing variabel.

\section{Uji F}

Dalam uji F Simultan ini digunakan untuk mengetahui pengaruh variabel independen secara bersama-sama mempengaruhi variabel dependen. Hasil uji simultan ini dilakukan dengan menggunakan E-Views. Hasil uji F dilihat pada tabel coefficient pada kolom prob $F$ statistic (significance). Jika probabilitas nilai signifikan 0,05 maka dapat diartikan bahwa terdapat pengaruh antara variabel independen (X1, X2, X3) simultan berpengaruh signifikan terhadap nilai variabel dependen (Y). 


\section{HASIL DAN PEMBAHASAN}

Tabel 1. Statistik Deskriptif

\begin{tabular}{lcccc}
\hline & PBY BAGI HASIL & CKPN & BIAYA DANA & LABA_RUGI \\
\hline Mean & 12.47842 & 8.818408 & 10.86855 & -252.0833 \\
\hline Median & 12.55364 & 8.999681 & 11.03473 & 476.0000 \\
\hline Maximum & 12.68624 & 9.603530 & 11.87073 & 8465.000 \\
\hline Minimum & 12.04890 & 6.249975 & 8.620111 & -6300.000 \\
\hline Std. Dev. & 0.190190 & 0.685910 & 0.779598 & 3861.748 \\
\hline Skewness & -0.850454 & -1.563349 & -0.953785 & 0.036319 \\
\hline Kurtosis & 2.438101 & 6.468663 & 3.451289 & 2.272102 \\
\hline Jarque-Bera & 4.813224 & & & 0.802669 \\
\hline Probability & 0.090120 & 32.71180 & 0.669426 \\
\hline Sum & 0.000000 & 0.056030 & -9075.000 \\
\hline Sum Sq. Dev. & 1.266029 & 317.4627 & 391.2677 & $5.22 \mathrm{E}+08$ \\
\hline Observations & 36 & 16.46655 & 21.27203 & \\
\hline
\end{tabular}

\section{Sumber : Data Olahan (2020)}

Berdasarkan tabel diatas maka variabel-variabel dalam penelitian ini dapat disimpulkan sebagai berikut:

- Pada variabel laba rugi pada hasil penelitian ini menghasilkan nilai minimum sebesar -6300.000 dan memiliki nilai maksimum sebesar 8465.000 sedangkan nilai rata-rata sebesar -252.0833 serta nilai standar deviasi sebesar 3861.748 .

- Pada variabel skema pembiayaan bagi hasil dalam penelitian ini memiliki nilai minimum sebesar 12.04890 dan memiliki nilai maksimum sebesar 12.68624 sedangkan nilai rata-rata sebesar 12.47842 serta nilai standar deviasi sebesar 0.190190 .
- Pada variabel CKPN dalam penelitian ini memiliki nilai minimum sebesar 6.249975 dan memiliki nilai maksimum sebesar 9.603530 sedangkan nilai rata-rata sebesar 8.818408 serta nilai standar deviasi sebesar 0.685910 .

- Pada variabel biaya dana dalam penelitian ini memiliki nilai minimum sebesar 8.620111 dan memiliki nilai maksimum sebesar 11.870873 sedangkan nilai ratarata sebesar 10.86855 serta nilai standar deviasi sebesar 0.779598 .

\section{Uji Normalitas}


Tabel 2. Hasil Uji Normalitas

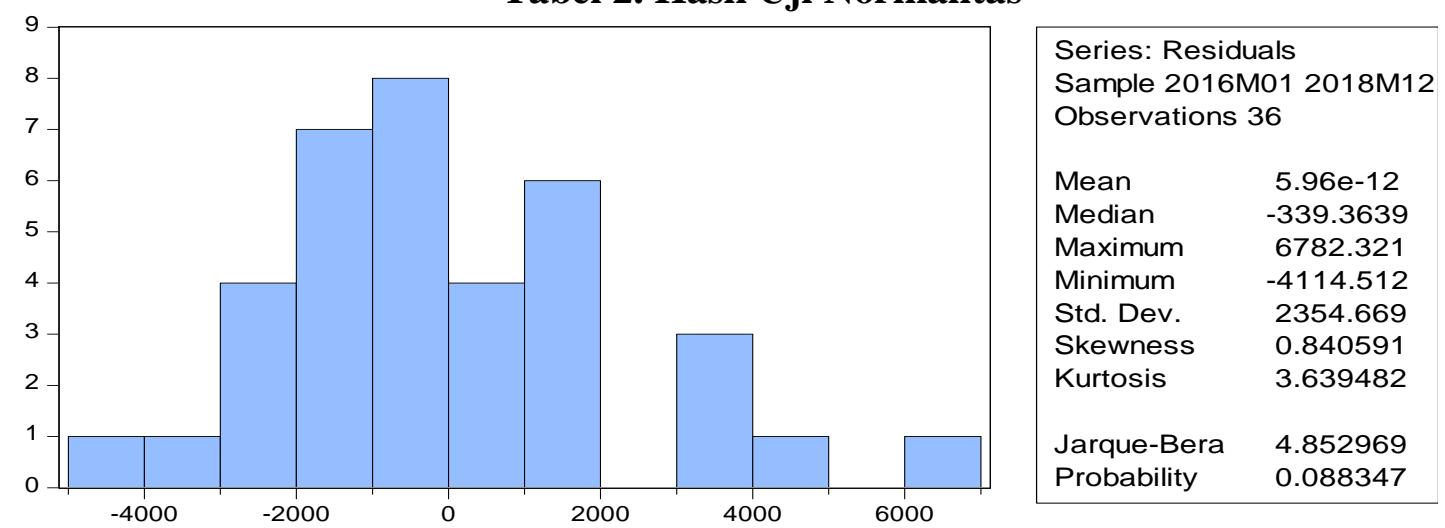

Sumber : Data Olahan (2020)

Dari tabel 2 diatas hasil probability sebesar $0.088347>0.05$ yang berarti $p>0.05$. Maka data ini dapat dikatakan terdistribusi normal seperti yang dijelaskan pada teori metode analisis data di bagian uji normalitas.

\section{Uji Asumsi Klasik}

Uji Multikolinearitas. Dari hasil uji multikolineritas dapat diambil kesimpulan nilai nilai VIF semua variabel $<10$ dan nilai tolerance semua variabel > 0.10 , sehingga dapat dikatakan bahwa model regresi tidak terdapat masalah multikolinieritas. Sehingga model regresi ini sudah dapat dikatakan baik dan layak untuk penelitian.
Uji Heterokedasitas. Dari hasil uji heteroskedastisitas diketahui bahwa masing-masing variabel bebas memiliki signifikansi lebih besar dari 0.05 maka dapat diketahui bahwa hasil model regresi yang digunakan tidak terjadi masalah heteroskedastisitas.

Uji Autokolerasi. Berdasarkan hasil uji Durbin Watson statistik, Durbin Watson statistik sesuai dengan kolom baris ke dua pada hasil pengujian Durbin Wastson Statistik. Maka keputusan yang dapat diambil adalah memenuhi asumsi Autokorelasi atau dapat dikatakan tidak mengalami masalah Autokorelasi.

Tabel 3. Least Squares

Dependent Variable: LABA_RUGI

Method: Least Squares

Date: $03 / 30 / 20$ Time: 22:23

Sample: 2016M01 2018M12

Included observations: 36

\begin{tabular}{lcccc}
\hline \hline Variable & Coefficient & Std. Error & t-Statistic & Prob. \\
\hline \hline C & -74868.27 & 33839.81 & -2.212432 & 0.0342 \\
PBY_BAGI_HASIL & 5835.217 & 2589.526 & 2.253392 & 0.0312 \\
CKPN & -3885.940 & 897.8106 & -4.328240 & 0.0001 \\
BIAYA_DANA & 3318.722 & 733.6052 & 4.523853 & 0.0001 \\
\hline \hline
\end{tabular}




$\begin{array}{llll}\text { R-squared } & 0.628215 & \text { Mean dependent var } & -252.0833 \\ \text { Adjusted R-squared } & 0.593360 & \text { S.D. dependent var } & 3861.748 \\ \text { S.E. of regression } & 2462.572 & \text { Akaike info criterion } & 18.56024 \\ \text { Sum squared resid } & 1.94 \mathrm{E}+08 & \text { Schwarz criterion } & 18.73619 \\ \text { Log likelihood } & -330.0843 & \text { Hannan-Quinn criter. } & 18.62165 \\ \text { F-statistic } & 18.02375 & \text { Durbin-Watson stat } & 0.955681 \\ \text { Prob(F-statistic) } & 0.000000 & & \end{array}$

Sumber : Data Olahan (2020)

Analisis Regresi Linier Berganda

\section{$\mathrm{Y}=-\mathbf{7 4 8 6 8 . 2 7}+\mathbf{5 8 3 5 . 2 1 7} \mathrm{X} 1+\cdot$ $3885.940 \mathrm{X} 2+3318.722 \mathrm{X} 3+\mathrm{e}$} (2)

Keterangan:

- Konstanta menggambarkan arah hubungan yang negatif, dengan nilai sebesar -74868.27. Artinya konstanta mengalami kenaikan sebesar satu satuan, maka laba/rugi akan menurun sebesar 6703.260 dan menunjukan hasil negatif.

- Skema pembiayaan bagi hasil menggambarkan arah hubungan yang positif, dengan nilai sebesar 5835.217. Artinya jika skema pembiayaan bagi hasil mengalami kenaikan sebesar satu satuan, maka laba/rugi akan mengalami kenaikan sebesar -5835.217 dan skema pembiayaan bagi hasil ini berpengaruh positif terhadap laba/rugi.

- CKPN menggambarkan arah hubungan yang negatif, dengan nilai sebesar 3885.940. Artinya jika CKPN mengalami kenaikan sebesar satu satuan, maka laba/rugi akan menurun sebesar 3885.940 dan CKPN ini berpengaruh negatif terhadap laba/rugi.

- Biaya dana menggambarkan arah hubungan yang positif, dengan nilai sebesar -3318.722. Artinya jika biaya dana mengalami kenaikan sebesar satu satuan, maka laba/rugi akan mengalami kenaikan sebesar 3318.722 dan biaya dana ini berpengaruh positif terhadap laba/rugi.

\section{Pengujian Hipotesis}

\section{Uji t-statistik}

Berdasarkan tabel diatas, Uji t ini digunakan untuk mengetahui seberapa jauh pengaruh variabel independen terhadap variabel dependen. Pembuktian dapat dilakukan dengan menggunakan EViews. Hipotesis 1 dan 2 dalam penelitian ini diuji kebenarannya dengan menggunakan uji parsial. Pengujian dilakukan dengan melihat taraf signifikansi, jika taraf signifikansi yang dihasilkan dari perhitungan dibawah 0,05 maka hipotesis diterima, sebaiknya jika taraf signifikansi hasil hitung lebih besar dari 0,05 maka hipotesis ditolak.

Pada hasil kesimpulan dalam penelitian ini adalah sebagai berikut: skema pembiayaan bagi hasil memiliki nilai prob (Sig. t) sebesar $0.0312<0,05$. Maka H0 ditolak dan H1 diterima, dapat disimpulkan bahwa skema pembiayaan bagi hasil berpengaruh signifikan terhadap laba/rugi dengan arah hubungan positif karena nilai t-statistik positif.

CKPN memiliki nilai prob (Sig. t) sebesar $0.0001<0,05$. Maka H0 ditolak dan H1 diterima, dapat disimpulkan bahwa CKPN berpengaruh signifikan terhadap laba/rugi dengan arah hubungan negatif karena nilai t-statistik minus. 
Biaya dana memiliki nilai prob (Sig. t) sebesar $0.0001<0,05$. Maka H0 ditolak dan H1 diterima, dapat disimpulkan bahwa biaya dana berpengaruh signifikan terhadap laba / rugi dengan arah hubungan positif karena nilai t-statistik positif.

\section{Uji F}

Hasil pengolahan data terlihat bahwa variabel independen $\left(\mathrm{X}_{1} \mathrm{X}_{2}\right.$ dan $\left.\mathrm{X}_{3}\right)$ signifikansi $\mathrm{F}$ hitung sebesar 18.02375 dengan tingkat signifikansi yang lebih kecil $(0,00000)$ dari 0,05. Dengan demikian hasil analisis dalam penelitian ini menunjukkan bahwa secara bersamasama variabel independen $\left(\mathrm{X}_{1} \mathrm{X}_{2}\right.$ dan $\left.\mathrm{X}_{3}\right)$ berpengaruh terhadap $\mathrm{Y}$ (laba/rugi). Dengan demikian hipotesis pertama (H1) dalam penelitian ini dapat diterima.

\section{KESIMPULAN}

Pada hasil ini menyimpulkan bahwa secara parsial dan simultan semua variabel independen yaitu skema pembiayaan bagi hasil, CKPN dan biaya dana berpengaruh signifikan terhadap laba/rugi. Berdasarkan hasil kesimpulan dari hasil penelitian, maka diajukan beberapa saran yaitu sebagai berikut:

(1) Bagi Bank Syariah. Dalam penelitian yang dilakukan bahwa bank syariah ini harus menjaga kolektabilitas pembiayaannya agar tidak memburuk yang berakibat meningkatkan biaya CKPN, dan bank syariah harus tetap berinovasi dalam mengembangkan produk pendanaannya supaya tidak banyak mencari dana mahal agar bisa menekan seminim mungkin biaya dana.

(2) Bagi peneliti selanjutnya, diharapkan penelitian selanjutnya dapat menambah variabel lain dari variabel penelitian ini.

\section{DAFTAR PUSTAKA}

Abbas, Ahmad \& Arizah, Ainun. 2019. Marketability, Profitability, and Profit-Loss Sharing: Evidence from Sharia Banking in Indonesia. Asian Journal of Accounting Research-Emerald Insight, (4)2.

Banoon, Malik. 2007. Prediksi Pertumbuhan Perbankan Syariah Di Indonesia Tahun 2008. Universitas Kristen Petra. Surabaya.

Darsono, Ali Sakti, \& Enny, Tin Suryanti. 2017. Masa Depan Keuangan Syariah Indonesia. Tazkia Publishing. Jakarta.

Dendawijaya, L. 2009. Manajemen Perbankan. Edisi Kedua. Ghalia Indonesia. Jakarta.

Kasmir. 2010. Manajemen Perbankan. PT. Raja Grafindo Persada. Jakarta.

Manurung, Mandala \& Rahardja, Prathama. 2004. Uang, Perbankan, dan Ekonomi Moneter. Jurnal Kajian Kontekstual Indonesia. Lembaga Penerbit FE-UI. Jakarta.

Mokoagow, Sri W. \& Fuady, Misbach. 2015. Faktor-Faktor yang Mempengaruhi Profitabilitas Bank Umum Syariah di Indonesia. Jurnal EBBANK. Vol. 6 No. 1 Juli 2018.

Molyneux, P., \& Thornton, J. 1992. Determinants of European bank Profitability: A note. Journal of banking \& Finance, 16(6), 11731178.

Riyadi, Slamet \& Yulianto, Agung. 2014. Pengaruh Pembiayaan Bagi Hasil, Pembiayaan Jual Beli, Financing To Deposit Ratio (FDR) Dan Non Performing Financing (NPF) Terhadap Profitabilitas Bank Umum Syariah Di Indonesia. 
2020, Jurnal Tabarru' : Islamic Banking and Finance 3 (2) : 137 - 151

Accounting Analysis Journal AAJ, $3(4)$.

Sanusi, Anwar. 2011. Metode Penelitian Bisnis. Salemba Empat. Jakarta.

Suryani. 2011. Analisis Pengaruh Financing To Deposit Ratio Terhadap Profitabilitas Perbankan Syariah Di Indonesia. Jurnal Walisongo STAIN Malikus Saleh Lhokseumawe, (19) 1, 48-49.

Zaenudin, Z., \& Erlina, Y. 2013. Pengaruh Pembiayaan Mudhârabah dan Musyârakah terhadap Pendapatan Bank Syariah. Al-Iqtishad: Jurnal Ilmu Ekonomi Syariah, 5(1). 